\title{
Determinants of the family physical fitness youth with selected disabilities
}

\begin{abstract}
Michał Karasinski, Determinants of the family physical fitness youth with selected disabilities. Interdisciplinary Contexts of Special Pedagogy, no. 31, Poznań 2020. Pp. 201-220. Adam Mickiewicz University Press. ISSN 2300-391X. e-ISSN 2658-283X. DOI: https://doi.org/10.14746/ikps.2020.31.09

The subject of this thesis was the physical fitness of youth with mild intellectual disability, and youth with hearing impairment. The aim of the research was to determine the family factors that affect the results of physical fitness. In the research work, particular attention was paid to: family factors, family structure, educational methods, application of rewards and punishments, parenting style, and socioeconomic status of the family. The practical purpose of this research was to develop practical guidelines for parents to stimulate their children to a higher level of physical fitness development.
\end{abstract}

KEY WORDS: physical activity, special school, disability, family factors

\section{Introduction}

Taking specialist literature and our own experience into consideration, the subject of this thesis was physical fitness of young students with mild intellectual disability and young students with hearing impairment. The aims of the research were as follows: identification of family factors that determine the above mentioned physical fitness, the appropriate attitude to physical activity and 
development of relevant guidelines both for parents and teachers who work with students with special educational needs.

The term 'disability' refers to various functional limitations of each society members resulting from inability to do activities in a way that is perceived as normal and typical of human life. These limitations can be permanent or temporary, complete or partial, and refer to the sensory, physical and emotional spheres. ${ }^{1}$

The human population comprises $3 \%$ of people with intellectual disabilities. Among these individuals, a major group consists of people with mild disability $(75 \%)$, then with moderate disability $(20 \%$ of the population) and severe disability (5\%). This group is highly diverse and there may be pronounced individual disproportions between peers of the same intelligence level and the social maturity. ${ }^{2}$

Cognitive disorders in people with mild disability are characterised by worsened functioning of: memory, perception, learning, attention, speech as well as reading and writing skills. ${ }^{3}$ Concerning relationships with people with mild intellectual disability, interpersonal skills include: the ability to build relationships, responsibility, self-evaluation, tendency to be manipulated and avoiding dangers. ${ }^{4}$

An analysis of nomenclature related to people with hearing impairment revealed a serious problem with deaf education terminology. This problem has existed for years and the concepts of terms or definitions regarding disabled people are still a subject of scientific discourse.

1 W. Dykcik, Pedagogika Specjalna, Wydawnictwo Naukowe UAM Poznań 1997, cited in: Z. Gajdzica, Uczeń z niepetnosprawnością w szkole ogólnodostępnej, Oficyna Wydawnicza HUMANITAS, Sosnowiec 2011, p. 46.

${ }^{2}$ K. Barłóg, Wspomaganie rozwoju, Uniwersytet Rzeszowski, 2008, cited in: B. Bolach. Sprawność fizyczna i postawa ciała uczniów z niepetnosprawnościa intelektualna w wieku 9-15 lat z uwzględnieniem aspektów socjodemograficznych. Na przykładzie wybranych placówek szkolno-wychowawczych w Polsce i w Czechach. AWF Wrocław 2017, p. 5.

${ }^{3}$ K. Ćwirynkało, Społeczne funkcjonowanie osób z lekką niepetnosprawnościa intelektualna (w kontekście ich autonomii i podmiotowości). Akapit, Toruń 2010, pp. 40-42

${ }^{4}$ R. Luckasson, Mental Retardation. Definition, Classification and System of Supports (10 th Edition), AAMR, Washington D.C. 2002, cited in: K. Ćwirynkało, Społeczne funkcjonowanie osób z lekką niepełnosprawnością intelektualna (w kontekście ich autonomii i podmiotowości). Akapit, Torun 2010, p. 42. 
According to Szczepankowski, 'a person with mild, moderate, severe or profound hearing impairment is a person whose audiogram excesses the threshold value of $20 \mathrm{~dB}$ (BIAP standards) that qualifies him/her to one of the impairment level' ${ }^{5}$

In medicine and pedagogy, authors suggest a classification that relates to the moment of hearing impairment formation, according to which deafness can be divided into:

a) Prelingual deafness (before a child can speak, 2 to 3 years of age),

b) Perilingual deafness (time of learning to speak, 3 to 5 years of age),

c) Postlingual deafness (after 5 years of age). ${ }^{6}$

The International Bureau for Audiophonology (BIAP) suggests the use of 'hearing impairment' term instead of 'deafness' due to a too pejorative meaning of the latter. Thus, according to the BIAP classification, we should mention adults or children with mild, moderate, severe or profound hearing impairment. ${ }^{7}$ Social conditions of physical fitness constitute an important component of diagnosis to better illustrate characteristics of disabled people. Attitudes of a part of society towards disabled people are reluctant and even hostile in some cases. In addition to a negative emotional attitude and avoidance of contacts, social prejudice may have a stable and permanent nature. ${ }^{8}$ Therefore, we should remember that sports activities may help young people with intellectual disability achieve a sense of self-esteem and belonging to a group that recognises socially accepted values. ${ }^{9}$

${ }^{5}$ B. Szczepankowski, W obronie głuchoniemego - rozważania nad terminologia. Problemy Rehabilitacji Społecznej i Zawodowej, 1(151), Warszawa 1997, p. 113.

${ }^{6}$ B. Szczepankowski, Niestyszacy - Gtusi - Głuchoniemi. Wyrównywanie szans, WSiP, Warszawa 1999, p. 38.

${ }^{7}$ O. Perier, Dziecko z uszkodzonym narządem stuchu. WSiP, Warszawa 1992, pp. 16-17.

8 S. Kowalik, Psychospołeczne podstawy rehabilitacji osób niepetnosprawnych. Interart, Warszawa 1996, p. 165.

${ }_{9}^{9}$ W. Dłużewska-Martyniec, Aktywność sportowa osób z niepetnosprawnościa intelektualną, [in:] S. Kowalik (red.) Kultura fizyczna osób z niepetnosprawnością. Dostosowana aktywność ruchowa, Gdańskie Wydawnictwo Psychologiczne, p. 436. 


\section{Study objective}

From a research perspective, the effects of family factors on the respondents' physical fitness (Tabak 2013, Szklarska 1998) as well as various parenting forms and styles (Przetacznik-Gierowska 1998, Górnicka 2007, Róg 2013) were analysed, being a subject of further empirical research in the context of young people without disabilities and the youth with selected disabilities.

The research work was mainly directed at family factors: a family structure, parenting methods, the use of reward and punishment system, a style of parents' upbringing, the socioeconomic status of a family.

\section{Methods}

In this project, questionnaires and testing methods were applied. One of three research tools was the Questionnaire for Parents of Children with Mild Intellectual Disability and Parents of Children with Hearing Impairment (it includes the metrics, information on the structure and the socioeconomic status of a family and other information about the study subjects). In addition to the questionnaire, the Eurofit Physical Fitness Test Battery and the Analysis of Parenting Style by M. Ryś10 were applied.

\section{Study group selection}

A target sample in this project was a group of students at the second educational stage. The students with disabilities attended only Special Schools. This age group was selected because changes in development of students' physical fitness can be evaluated best at

${ }^{10}$ M. Ryś, Systemy rodzinne. Metody badań struktury rodziny, pochodzenia i rodziny własnej, Centrum Medyczne Pomocy Psychologiczno-Pedagogicznej, Warszawa 2004, pp. 55-60. 
this stage of life. They can progressively and successfully acquire physical skills, such as swimming, jumping into water, skating and skiing. They also make fast progress regarding playing an instrument or painting, particularly when they start this activity on their own without external pressure. ${ }^{11}$ The whole study group included:

a) students without disabilities (control group)

b) students with mild intellectual disability

c) students with hearing impairment

The first two groups consisted of 50 students each while the group of hearing impaired students consisted of 25 students. In total, the study group comprised 125 students at the second educational stage, i.e. classes 4 to 6 . However, the age range was 11 to 15 years due to various earlier educational problems.

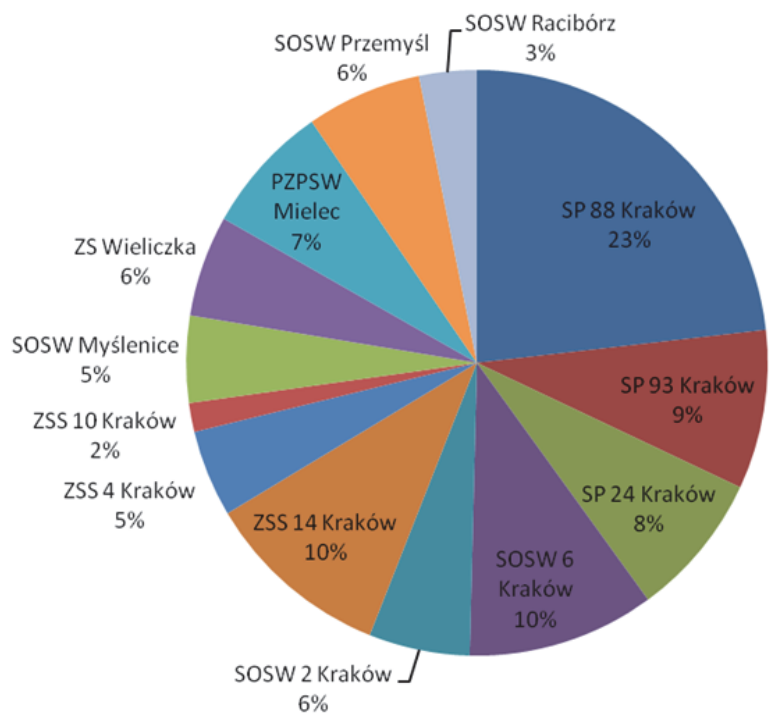

Figure 1. Percentage of all researched schools

Source: the authors

${ }^{11}$ J. Trempała, Psychologia rozwoju człowieka, PWN, Warszawa 2011, p. 235. 


\section{Study results}

The study findings show that the socioeconomic status only partially affects the quality of the Eurofit fitness testing being done by the study subjects. In the group of students with mild intellectual disability, good socioeconomic conditions were related to better results in the standing broad jump $(R=0.28)$ and flexibility $(\mathrm{R}=0.31)$ tests, while better financial conditions of a family correlated with significantly lower results of flexibility testing among the students with hearing impairment $(R=-0.45)$.

Table 1. Living conditions and the educational level of parents versus physical fitness of the study subjects (Spearman's rho correlations)

\begin{tabular}{|c|c|c|c|c|}
\hline \multicolumn{2}{|c|}{ Group } & $\begin{array}{c}\text { Living } \\
\text { conditions }\end{array}$ & $\begin{array}{c}\text { Mother's } \\
\text { education level }\end{array}$ & $\begin{array}{c}\text { Father's } \\
\text { education level }\end{array}$ \\
\hline \multirow{10}{*}{$\begin{array}{l}\text { Students with } \\
\text { mild intellectual } \\
\text { disability }\end{array}$} & Balance & .20 & -.17 & $-.31^{*}$ \\
\hline & Plate tapping & .17 & -.08 & -.27 \\
\hline & Standing broad jump & $.28^{*}$ & -.13 & $-.33^{*}$ \\
\hline & Hand grip test & .04 & -.09 & $-.28^{*}$ \\
\hline & Sit-ups & .27 & -.14 & -.26 \\
\hline & Bent arm hang & .09 & -.07 & -.14 \\
\hline & Beep test & .19 & -.13 & $-.30^{*}$ \\
\hline & $10 \times 5 \mathrm{~m}$ run & .18 & -.10 & $-.28^{*}$ \\
\hline & Flexibility & $.31^{*}$ & -.20 & $-.29 *$ \\
\hline & TOTAL & .28 & -.18 & $-.39 * *$ \\
\hline \multirow{10}{*}{$\begin{array}{l}\text { Students with } \\
\text { hearing } \\
\text { impairment }\end{array}$} & Balance & -.16 & .27 & .26 \\
\hline & Plate tapping & -.26 & -.07 & -.07 \\
\hline & Standing broad jump & -.20 & .19 & .16 \\
\hline & Hand grip test & -.31 & -.11 & -.20 \\
\hline & Sit-ups & -.10 & -.13 & -.12 \\
\hline & Bent arm hang & .16 & .15 & .02 \\
\hline & Beep test & .04 & .13 & .19 \\
\hline & $10 \times 5 m$ run & -.11 & -.09 & -.04 \\
\hline & Flexibility & $-.45^{\star}$ & .05 & .02 \\
\hline & TOTAL & -.38 & .03 & .01 \\
\hline
\end{tabular}

$*: p<.05^{* *}: p<.01$ Source: the authors 
The study demonstrates that a mother's educational level does not directly affect physical fitness of the research students. Interestingly, the education level of a father of a child with mild intellectual disability negatively correlated with the results of physical fitness testing in as many as six out of nine tests and the overall score $(\mathrm{R}=-0.39)$.

The study findings show that a number of children in a family does not significantly diversify physical fitness of the study subjects. The only statistically significant correlation referred to the $10 \times 5 \mathrm{~m}$ agility run test. In this case, the children with hearing impairment in complete families did better in physical fitness tests than their peers from other family types. Therefore, it can be concluded that both many children in a family and the family structure do not significantly determine physical fitness in the two dysfunctional groups.

Table 2. Family structure and a number of children in the family versus physical fitness of the study subjects (Spearman's rho correlations)

\begin{tabular}{|l|c|c|c|c|}
\hline \multirow{2}{*}{\multicolumn{1}{|c|}{$\mathrm{p}$}} & \multicolumn{2}{|c|}{$\begin{array}{c}\text { Students with mild intellectual disability } \\
(\mathrm{N}=50)\end{array}$} & \multicolumn{2}{c|}{$\begin{array}{c}\text { Students with hearing impairment } \\
(\mathrm{N}=25)\end{array}$} \\
\cline { 2 - 5 } & $\begin{array}{c}\text { Number of children } \\
\text { in the family }\end{array}$ & Family structure & $\begin{array}{c}\text { Number of children } \\
\text { in the family }\end{array}$ & Family structure \\
\hline Balance & .14 & .02 & -.24 & -.03 \\
\hline Plate tapping & .25 & -.05 & -.09 & .34 \\
\hline $\begin{array}{l}\text { Standing broad } \\
\text { jump }\end{array}$ & -.01 & -.13 & .06 & .27 \\
\hline Hand grip test & .00 & .03 & .27 & .03 \\
\hline Sit-ups & .13 & .10 & -.01 & .20 \\
\hline Bent arm hang & .19 & -.13 & -.03 & .13 \\
\hline Beep test & .08 & -.13 & -.20 & -.26 \\
\hline $10 \times 5$ m run & .11 & -.16 & .25 & $.40^{*}$ \\
\hline Flexibility & -.01 & -.05 & .09 & .14 \\
\hline TOTAL & .18 & -.05 & .02 & .21 \\
\hline
\end{tabular}

$*: p<.05$ Source: the authors 
While analysing the aspect of parenting methods, it could be concluded that among the study parents of children with hearing impairment, not all the questionnaire answers were used. Therefore, correlations were not determined as there is no variance for the variable (for all the study parents, the result is the same: zero).

Table 3. Parenting methods versus physical fitness among the study subjects (Spearman's rho correlations)

\begin{tabular}{|c|c|c|c|c|c|c|}
\hline Group & $-\mathrm{p}$ & $\begin{array}{l}\text { Beating, } \\
\text { shouting }\end{array}$ & Conversation & $\begin{array}{c}\text { Pleasure } \\
\text { refusal }\end{array}$ & Praising & $\begin{array}{c}\text { Giving good } \\
\text { examples }\end{array}$ \\
\hline \multirow{10}{*}{$\begin{array}{l}\text { Students with } \\
\text { mild } \\
\text { intellectual } \\
\text { disability }\end{array}$} & Balance & -.01 & .10 & -.14 & $-.40^{* *}$ & $-.29 *$ \\
\hline & Plate tapping & .14 & -.07 & -.11 & $-.34^{*}$ & -.21 \\
\hline & $\begin{array}{l}\text { Standing } \\
\text { broad jump }\end{array}$ & -.13 & .13 & .00 & $-.31^{*}$ & .06 \\
\hline & Hand grip test & .02 & -.20 & -.14 & $-.30^{*}$ & .03 \\
\hline & Sit-ups & -.06 & -.08 & -.09 & $-.34^{*}$ & -.02 \\
\hline & Bent arm hang & -.03 & -.16 & .06 & -.18 & .19 \\
\hline & Beep test & .09 & .09 & -.15 & $-.31^{*}$ & -.06 \\
\hline & $10 \times 5 \mathrm{~m}$ run & .04 & -.07 & -.13 & $-.39 * *$ & .01 \\
\hline & Flexibility & -.25 & -.08 & -.07 & $-.34^{*}$ & -.10 \\
\hline & TOTAL & -.06 & -.01 & -.15 & $-.45^{* *}$ & -.09 \\
\hline \multirow{10}{*}{$\begin{array}{l}\text { Students with } \\
\text { hearing } \\
\text { impairment }\end{array}$} & Balance & & & -.04 & .29 & .36 \\
\hline & Plate tapping & & & .10 & .16 & .20 \\
\hline & $\begin{array}{l}\text { Standing } \\
\text { broad jump }\end{array}$ & & & .18 & $.62^{* *}$ & .15 \\
\hline & Hand grip test & & & .07 & .03 & -.13 \\
\hline & Sit-ups & & & .29 & -.03 & -.02 \\
\hline & Bent arm hang & & & -.19 & .19 & -.11 \\
\hline & Beep test & & & .07 & .27 & $.53^{* *}$ \\
\hline & $10 \times 5 \mathrm{~m}$ run & & & .20 & $.47^{*}$ & .05 \\
\hline & Flexibility & & & .29 & $.48^{*}$ & .22 \\
\hline & TOTAL & & & .14 & $.48^{*}$ & .31 \\
\hline
\end{tabular}

$*: p<.05 ; * *: p<.01$ Source: the authors

The statistical analysis showed numerous, very interesting negative correlations for praise in the group of children with mild disability, which means that praising by parents seems to be related to 
poorer physical fitness. This refers to as many as eight out of nine physical fitness tests of interest and the overall score and means that praising, as a parenting method that is used by parents of children with mild intellectual disability, is a demotivating factor for the children and their fitness scores.

Completely different results are seen among the children with hearing impairment: here, parental praising is connected with higher fitness results regarding standing broad jump $(R=0.62)$, the agility run test $(10 \times 5 \mathrm{~m}$ run $)(R=0.47)$, flexibility $(R=0.48)$ and the overall score $(\mathrm{R}=0.48)$. According to the statistical analysis, a parenting method of giving good examples leads to better fitness scores (the beep test) among the children with hearing impairment; yet, the group of students with mild intellectual disability score worse statistically regarding the balance tests.

An interesting fact in this analysis is that the same parenting method can be a motivating factor for one study group (encouraging the students to take up activities) while it can have a relaxing effect on the other group, which results in worse individual physical fitness scores among the study subjects.

Based on the research analysis, it can be concluded that both the amount of time for a conversation with a child and a type of interests, if any, do not significantly diversify physical fitness in either of the study groups. However, the students with mild intellectual disability who had some duties did better in standing broad jump, situps, bent arm hang and the overall score.

In the group of students with hearing impairment, having duties was related to better scores on the balance test $(R=0.42)$. Based on the statistical analysis, it can be seen that the students' specific duties positively correlate with certain physical fitness indicators. This may mean that considering duties, consciousness and reliability influence e.g. resourcefulness, which has a significant effect on the quality of fitness scores among the students in both dysfunctional groups.

There are surprising results concerning the effects of time spent with a child by a parent on his/her physical fitness. The study 
showed no statistically significant relationships, although it might seem that more attention given to a child should provide a better potential for more activating methods as well as raise movement awareness and purposefulness among the study participants.

Table 4. Time designated by the parents on conversations with the child, children's interests and duties versus physical fitness (Spearman's rho correlations)

\begin{tabular}{|l|c|c|c|c|c|c|}
\hline \multirow{2}{*}{} & \multicolumn{3}{|c|}{$\begin{array}{c}\text { Students with mild intellectual } \\
\text { disability }\end{array}$} & \multicolumn{2}{c|}{ Students with hearing impairment } \\
\cline { 2 - 7 } & $\begin{array}{c}\text { Time for } \\
\text { conversation }\end{array}$ & Interests & Duties & $\begin{array}{c}\text { Time for } \\
\text { conversation }\end{array}$ & Interests & Duties \\
\hline Balance & .21 & -.07 & .11 & -.05 & .26 & $.42^{*}$ \\
\hline Plate tapping & -.03 & -.13 & .21 & -.14 & .05 & .03 \\
\hline Standing broad jump & .05 & -.15 & $.31^{*}$ & -.04 & .31 & .19 \\
\hline Hand grip test & .01 & -.13 & .02 & -.25 & -.24 & -.33 \\
\hline Sit-ups & .05 & -.12 & $.29^{*}$ & -.36 & -.06 & -.12 \\
\hline Bent arm hang & .09 & -.17 & $.36^{*}$ & -.03 & .28 & .28 \\
\hline Beep test & .09 & -.10 & .27 & .25 & .02 & .37 \\
\hline $10 \times 5$ m run & .02 & -.18 & .26 & -.27 & .15 & -.13 \\
\hline Flexibility & .26 & -.13 & .24 & -.15 & .39 & -.04 \\
\hline TOTAL & .11 & -.20 & $.33^{*}$ & -.09 & .27 & .07 \\
\hline
\end{tabular}

$*: p<.05$ Source: the authors

The statistical analysis of the students' rewards showed that certain rewarding methods positively correlated with fitness in the group of students with mild intellectual disability. A reward of meeting a friend resulted in better results in flexibility tests. The students that marked the answer 'Other' in the Parenting methods category demonstrated high results in plate tapping $(R=0.29)$, bent arm hang $(R=0.30)$, agility run $(10 \times 5 \mathrm{~m}$ run $)(R=0.30)$ and the overall score $(R=0.32)$. The only reward that negatively affected the fitness scores of children with mild intellectual disability was praising mentioned previously. 


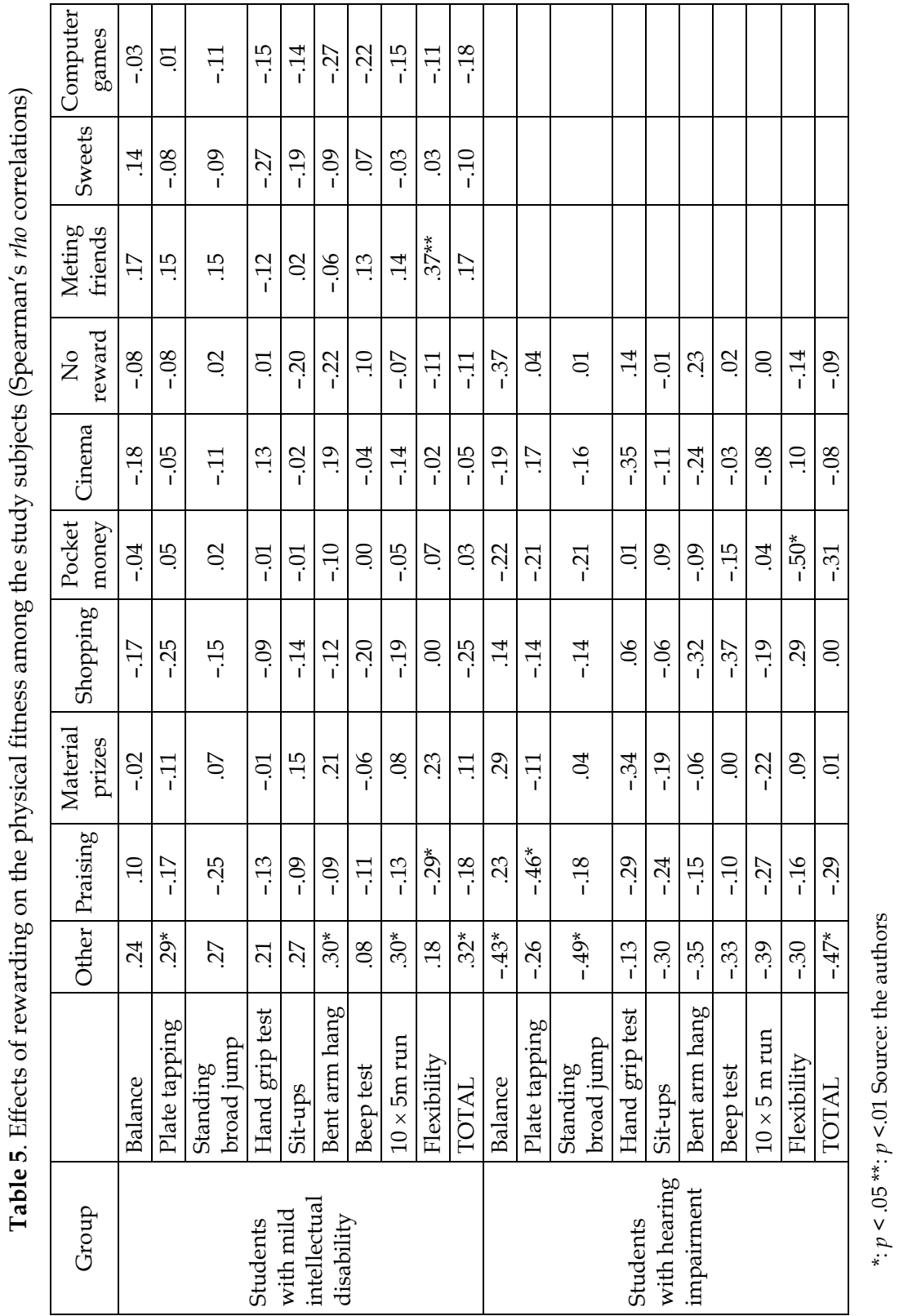


Among the children with hearing impairment, the answers 'Other' also correlated with physical fitness, but negatively in this case. The respondents did worse in the balance test $(R=-0.43)$, standing broad jump $(R=-0.49)$ and the overall score $(R=-0.47)$. Similarly to the analysis of the previous group, praising as a reward negatively diversify the fitness scores of the children with hearing impairment. This is a quite interesting relationship suggesting that positive conditions, such as 'a good word', approval or a compliment towards a child provided by the parents, result in some kind of relaxation, self-satisfaction and a poor motivation for further work. The same situation occurs with the flexibility scores that were significantly lower when the basic form of rewarding was the pocket money.

The statistical analysis of punishments applied by the parents revealed again a tendency for positive correlations considering the children with mild intellectual disability and negative ones concerning the children with hearing impairment for certain physical fitness scores.

Among the students with mild intellectual disability, no TV correlated with better general fitness and higher scores on the specific tests: plate tapping $(R=0.31)$, the beep test $(R=0.32)$ and the flexibility test $(R=0.34)$. It is also worth noting that the pleasure refusal positively influenced better physical fitness shown in the static strength test (the hand grip test) $(R=0.29)$.

The above analysis demonstrates an interesting relationship between the no TV punishment and the higher level of physical fitness of the students. It can be concluded that the students perform physically better when they cannot sit in front of TV, which makes them spend their leisure time in another way, such as physical training.

On the other hand, the students with hearing impairment showed worse scores in the agility run $(10 \times 5 \mathrm{~m}$ run $)(R=-0.48)$, standing broad jump $(R=-0.40)$ and manual skills (plate tapping) $(R=-0.42)$ testing when they were punished by their parents with no mobile. From the statistical point of view, very negative correlations between no punishment from the parents among the children with hearing impairment and poor balance scores are also important. 
The study shows that the students with hearing impairment tend to do worse in some physical fitness tests along with certain types of punishment. This can be a demonstration of their disapproval in situations when their parents intentionally take their mobile phones to achieve the parenting effect. The study findings suggest, however, a possibly opposite effect in the case of students with hearing impairment.

Table 6. Effects of punishment on the physical fitness among the study subjects (Spearman's rho correlations)

\begin{tabular}{|c|c|c|c|c|c|c|c|c|}
\hline \multicolumn{2}{|c|}{ Group } & Other & $\begin{array}{c}\text { No } \\
\text { computer } \\
\text { games }\end{array}$ & No TV & $\begin{array}{c}\text { No } \\
\text { punishment }\end{array}$ & $\begin{array}{c}\text { No } \\
\text { meeting } \\
\text { friends }\end{array}$ & $\begin{array}{c}\text { Pleasure } \\
\text { refusal }\end{array}$ & $\begin{array}{c}\text { No } \\
\text { telephone }\end{array}$ \\
\hline \multirow{10}{*}{$\begin{array}{l}\text { Students } \\
\text { with mild } \\
\text { intellectual } \\
\text { disability }\end{array}$} & Balance & -.07 & .02 & .12 & .18 & .13 & -.07 & .11 \\
\hline & Plate tapping & -.06 & .09 & $.31^{*}$ & -.14 & .19 & -.03 & .07 \\
\hline & $\begin{array}{l}\text { Standing } \\
\text { broad jump }\end{array}$ & -.01 & -.02 & .24 & -.02 & -.12 & -.07 & -.14 \\
\hline & Hand grip test & .19 & -.27 & .03 & .18 & .16 & $.29^{*}$ & -.18 \\
\hline & Sit-ups & .14 & -.12 & .23 & -.08 & .01 & .00 & .12 \\
\hline & Bent arm hang & .00 & .00 & .15 & -.15 & .01 & .01 & -.15 \\
\hline & Beep test & .02 & -.08 & $.32^{*}$ & .08 & .13 & -.22 & -.16 \\
\hline & $10 \times 5 \mathrm{~m}$ run & .04 & -.12 & .23 & -.01 & -.03 & .06 & -.08 \\
\hline & Flexibility & .07 & .04 & $.36^{*}$ & -.02 & .07 & -.15 & -.14 \\
\hline & TOTAL & .00 & -.01 & $.34^{*}$ & -.03 & .10 & -.05 & -.03 \\
\hline \multirow{10}{*}{$\begin{array}{l}\text { Students } \\
\text { with hearing } \\
\text { impairment }\end{array}$} & Balance & .20 & .24 & & $-.52^{* *}$ & .33 & -.18 & .02 \\
\hline & Plate tapping & -.17 & .05 & & -.14 & -.27 & .38 & $-.42 *$ \\
\hline & $\begin{array}{l}\text { Standing } \\
\text { broad jump }\end{array}$ & .11 & .05 & & -.14 & -.04 & .17 & $-.40^{*}$ \\
\hline & Hand grip test & -.03 & .06 & & .31 & -.35 & -.08 & -.26 \\
\hline & Sit-ups & -.26 & .38 & & .10 & -.16 & -.12 & -.24 \\
\hline & Bent arm hang & .16 & .13 & & -.08 & -.02 & .02 & .03 \\
\hline & Beep test & .28 & .00 & & -.15 & .06 & .16 & -.38 \\
\hline & $10 \times 5 \mathrm{~m}$ run & -.28 & .17 & & -.04 & -.12 & .17 & $-.48^{*}$ \\
\hline & Flexibility & -.06 & -.01 & & -.01 & -.01 & .06 & -.14 \\
\hline & TOTAL & .08 & .12 & & -.13 & -.08 & .14 & -.39 \\
\hline
\end{tabular}

Source: the authors. 


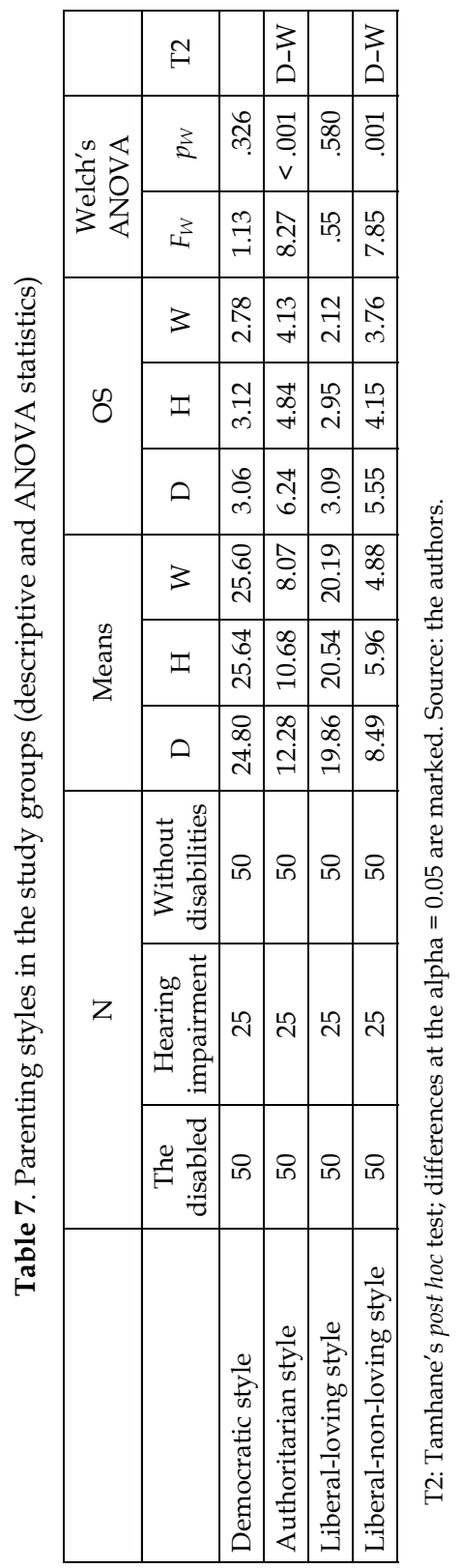


Table 8. Correlations between the family parenting methods and physical fitness in the study groups (Spearman's rho correlations)

\begin{tabular}{|c|c|c|c|c|c|}
\hline Group & & $\begin{array}{c}\text { Democratic } \\
\text { style }\end{array}$ & $\begin{array}{c}\text { Authoritar } \\
\text { ian style }\end{array}$ & $\begin{array}{c}\text { Liberal- } \\
\text { loving style }\end{array}$ & $\begin{array}{c}\text { Liberal-non- } \\
\text { loving style }\end{array}$ \\
\hline \multirow{10}{*}{ Disabled students } & Balance & -.07 & .02 & .05 & .14 \\
\hline & Plate tapping & .01 & -.19 & .16 & .05 \\
\hline & $\begin{array}{l}\text { Standing broad } \\
\text { jump }\end{array}$ & .13 & -.11 & .21 & .01 \\
\hline & Hand grip test & -.02 & -.10 & .01 & .04 \\
\hline & Sit-ups & -.05 & .12 & .15 & $.29 *$ \\
\hline & \begin{tabular}{|l|} 
Bent arm hang \\
\end{tabular} & .25 & $-.32^{*}$ & .06 & -.10 \\
\hline & Beep test & .08 & -.03 & .21 & .20 \\
\hline & $10 \times 5 \mathrm{~m}$ run & .11 & -.15 & .12 & .01 \\
\hline & \begin{tabular}{|l} 
Flexibility \\
\end{tabular} & .13 & .11 & .14 & .05 \\
\hline & TOTAL & .09 & -.11 & .18 & .10 \\
\hline \multirow{10}{*}{$\begin{array}{l}\text { Students with } \\
\text { hearing impairment }\end{array}$} & Balance & .21 & .11 & .25 & -.23 \\
\hline & Plate tapping & .28 & .38 & .22 & .12 \\
\hline & $\begin{array}{l}\text { Standing broad } \\
\text { jump }\end{array}$ & -.05 & .11 & -.10 & -.12 \\
\hline & Hand grip test & -.29 & .09 & -.06 & .31 \\
\hline & Sit-ups & -.32 & $.41^{*}$ & .07 & $.42^{*}$ \\
\hline & Bent arm hang & .00 & .24 & .05 & -.06 \\
\hline & Beep test & .05 & .23 & .00 & .01 \\
\hline & $10 \times 5 \mathrm{~m}$ run & -.11 & .30 & -.15 & .07 \\
\hline & Flexibility & -.04 & .01 & .01 & -.07 \\
\hline & TOTAL & .01 & .30 & .05 & .09 \\
\hline \multirow{10}{*}{$\begin{array}{l}\text { Students without } \\
\text { disabilities }\end{array}$} & Balance & -.13 & .08 & -.12 & .10 \\
\hline & Plate tapping & .17 & .02 & .19 & .04 \\
\hline & $\begin{array}{l}\text { Standing broad } \\
\text { jump }\end{array}$ & -.15 & -.05 & -.14 & .12 \\
\hline & Hand grip test & .17 & -.08 & .25 & -.07 \\
\hline & Sit-ups & -.08 & .11 & -.11 & .10 \\
\hline & Bent arm hang & $-.34^{*}$ & .18 & -.21 & $.31^{*}$ \\
\hline & Beep test & $-.33^{*}$ & .08 & -.08 & .27 \\
\hline & $10 \times 5 \mathrm{~m}$ run & -.08 & .12 & -.12 & -.05 \\
\hline & Flexibility & $-.28^{*}$ & .03 & $-.37^{* *}$ & .25 \\
\hline & TOTAL & -.25 & .05 & -.19 & .23 \\
\hline
\end{tabular}

${ }^{*}: \mathrm{p}<.05 ; * * \mathrm{p}<.01$ Source: the authors 
The Parenting style has never been investigated in the context of physical fitness. However, it was important to diagnose whether there were statistically significant relationships between the way of parents' upbringing and the students' physical fitness scores. Initially, mean values were calculated separately for three groups and the statistical significance of differences was determined (Welch's ANOVA). In the analysis of parenting style among the school students, a group without physical disabilities (the control group) attending public primary schools was included.

The analysis showed that among the students without disabilities, the democratic style negatively correlated with certain fitness scores: bent arm hang $(R=-0.34)$, agility run $(R=-0.33)$ and flexibility $(R=-0.28)$. As a result, the children without disabilities, brought up in the atmosphere of democratic parenting style, scored worse during the selected Eurofit tests. On the other hand, the authoritarian style negatively correlated with the bent arm hang $(R=-0.32)$ scores among the children with mild intellectual disability, but positively with the scores of the children with hearing impairment considering sit-ups $(\mathrm{R}=-0.41)$.

The children without disabilities in families preferring a liberalloving style did better in the flexibility test $(R=-0.37)$, while a liberal-non-loving style, rarely preferred by parents, positively correlated in each of the three study groups. The children with mild intellectual disability did better in the sit-ups $(R=-0.29)$, the students without disabilities improved on the bent arm hang test $(R=-0.31)$ and the students with hearing impairment also scored better regarding the sit-ups $(\mathrm{R}=0.42)$.

\section{Discussion}

Problems of physical fitness regarding children with selected disabilities have been a subject of many publications and scientific analyses (e.g. Fidelus 1998, Jankowicz-Szymańska 2011). Among many literature items concerning physical fitness, there is a paper which partially relates to the research questions of our project. 
In her article, A Jankowicz-Szymańska12 compares physical fitness among children, specifying the same groups with disabilities. While assessing the above statistical analysis in the study groups, the author concluded that the level of motor fitness among the children with hearing impairment is slightly worse than that of the study participants without disabilities, while the poorest results were seen among the children with mild intellectual disability. ${ }^{13}$

In his research including 125 students of the primary school in Jarosławiec (primary class 6 as well as middle-school classes 1 and 2), Kaczor-Szkodny suggested that 'development of digital technologies prevents children and adolescents from traditional forms of physical activity. They choose computer entertainment'. ${ }^{14}$

To date, research on the relationship between the families' structure and their physical activity has not yielded an unequivocal answer. ${ }^{15}$ Some of the scientists even suggest that 'a divorce can be a minor negative factor that affects a child compared to a constantly unstable atmosphere of quarrel and hostility between the parents. ${ }^{16}$

Parents' education is a factor that strongly diversifies physical fitness both among girls and boys; however, the father's education in each separately analysed age group has a significantly stronger

12 A. Jankowicz-Szymańska, W. Wojtanowski, M. Chronowski, T. Ridan, Porównanie motoryczności dzieci petnosprawnych, niestyszacych i niepetnosprawnych intelektualnie w stopniu lekkim. Niepełnosprawność i Rehabilitacja 1(1), Warszawa 2011, pp. 55-67.

${ }^{13}$ A. Jankowicz-Szymańska, W. Wojtanowski, M. Chronowski, T. Ridan, Porównanie motoryczności dzieci petnosprawnych, niestyszacych i niepetnosprawnych intelektualnie w stopniu lekkim. Niepełnosprawność i Rehabilitacja 1(1), Warszawa 2011, p. 67.

${ }^{14}$ P. Kaczor-Szkodny, C.A. Horoch, T.B. Kulik, A. Pacian, E. Kawiak-Jawor, M. Kaczoruk, Aktywność fizyczna i formy spędzania czasu wolnego wśród uczniów w wieku 12-15 lat, Medycyna Ogólna i Nauka o Zdrowiu, Vol. 22, no 2, Lublin 2016, p. 116.

${ }^{15}$ I. Ferreira, K. Horst, W. Wendel-Vos, S. Kremers, F.J. van Lenthe, J. Brug. Environmental determinants of physical activity in youth: a review and update. Obes Rev 8, pp. 129-154, 2006, cited in: I. Tabak, Struktura i funkcjonowanie rodziny, a aktywność fizyczna młodzieży, [in:] Aktywność fizyczna młodzieży szkolnej w wieku 9-17 lat. Aktualne wyniki, tendencje ich zmian oraz wybrane zewnętrzne $i$ wewnętrzne uwarunkowania. Raport końcowy. Instytut Matki i Dziecka, Warszawa 2013, p. 155.

${ }^{16}$ J. Cieślińska, Style wychowania w rodzinie. Remedium 7-8, Warszawa 2015, p. 19. 
impact on children's fitness than their mother's education level. ${ }^{17}$ Higher education of the parents is strictly related to a higher level of physical fitness due to a better life standard18 (e.g. Przewęda 1985, 1998, Dąbrowski 2009, Charzewski 1988).

\section{Final conclusions}

The research findings have led to constructive conclusions:

a) The family structure did not translate into physical fitness of the study subjects.

b) Praising, as a parenting method, diversifies physical fitness among the study subjects depending on their disability.

c) Rewarding does not translate into physical fitness of the study subjects.

d) Specific punishments significantly determine the quality of physical fitness among the study subjects.

e) The parenting style and physical fitness of the study subjects do not correlate.

f) The father's education level negatively diversifies the physical fitness level of the students with mild intellectual disability.

The final conclusions let me formulate a few postulates for parents of children with the above disabilities:

- Duties and their fulfilment by children will help parents teach them about responsibility or self-reliance.

- Assistance in discovering leisure activities other than information technology devices.

- Stable monitoring of a child's fitness progress.

17 A. Szklarska, Społeczne różnice w sprawności fizycznej dzieci i młodzieży w Polsce, Monografie Zakładu Antropologii PAN, Wrocław 1998, p. 28.

18 W. Osiński, 2003. Antropomotoryka, AWF Poznań, cited in: D. Dąbrowski, Wewnętrzne uwarunkowania zdolności motorycznych dzieci i młodzieży z dysfunkcjami narządu słuchu, Wychowanie Fizyczne i Zdrowotne (7), 2009383. 
- An exact analysis of praising as a parenting method to achieve appropriate progress in proper social, psychological and motor development.

The Welch's ANOVA showed that the authoritarian $(p<0.001)$ and liberal-non-loving $(p=0.001)$ styles were more intense in the groups of students with mild intellectual disability compared to the group of students without disabilities. As a result, the children without disabilities, brought up in the atmosphere of democratic parenting style, scored worse during the selected Eurofit tests.

Also, an interesting fact in this analysis is that the same parenting method (praising) can be a motivating factor for one study group (encouraging the students to take up activities), while it can have a relaxing effect on the other group, which results in worse individual physical fitness scores among the study subjects.

\section{References}

Barłóg K. 2008, Wspomaganie rozwoju. Uniwersytet Rzeszowski.

Bolach B. 2017, Sprawność fizyczna i postawa ciała uczniów z niepetnosprawnościa intelektualna w wieku 9-15 lat z uwzględnieniem aspektów sojo demograficznych. Na przykładzie wybranych placówek szkolno-wychowawczych w Polsce i w Czechach. AWF Wrocław.

Charzewski J.. Przewęda R. 1988, Niektóre spoteczne uwarunkowania rozwoju fizycznego i sprawności polskich dzieci, [w:] Pilicz S. (red.), Rozwój sprawności i wydolności fizycznej dzieci i młodzieży. Wyd. AWF Warszawa.

Cieślińska J. 2015, Style wychowania w rodzinie. Remedium, 7-8, pp. 19-21.

Ćwirynkało K. 2010, Spoteczne funkcjonowanie osób z lekka niepetnosprawnościa intelektualna (w kontekście ich autonomii i podmiotowości). Akapit. Toruń.

Dąbrowski D. 2009, Wewnętrzne uwarunkowania zdolności motorycznych dzieci i młodzieży $z$ dysfunkcjami narzadu stuchu. Wychowanie fizyczne i Zdrowotne, (7), pp. 12-19.

Dykcik W. 1997, Pedagogika Specjalna. Wydawnictwo Naukowe UAM, Poznań.

Fidelus K. 1998, Porównanie poziomu wytrzymałości u osób styszących i niestyszacych. Wychowanie Fizyczne i Sport. nr 1, pp. 81-87.

Gajdzica Z. 2011, Uczeń z niepetnosprawnościa w szkole ogólnodostępnej. Oficyna Wydawnicza HUMANITAS. Sosnowiec. 
Górnicka B. 2007, Rodzina w działalności profilaktycznej wobec dzieci i młodzieży, [w:] Profilaktyka spoteczna w środowisku otwartym. Konteksty krajowe $i$ zagraniczne, (red.) M. Hanulewicz, D. Widelak. WSZiA w Opolu.

Jankowicz-Szymańska A., Wojtanowski W., Chronowski M., Ridan T. 2011, Porównanie motoryczności dzieci petnosprawnych, niestyszacych i niepetnosprawnych intelektualnie w stopniu lekkim. Niepełnosprawność i Rehabilitacja 1(1), pp. 55-67.

Kaczor-Szkodny P., Horoch C.A., Kulik T.B., Pacian A., Kawiak-Jawor E., Kaczoruk M. 2016, Aktywność fizyczna i formy spędzania czasu wolnego wśród uczniów w wieku 12-15 lat. Medycyna Ogólna i Nauka o Zdrowiu. Tom 22, nr 2, pp. 113-119.

Luckasson R. 2002, Mental Retardation. Definition. Classyfication and System of Supports (10 th Edition). Wyd. AAMR. Washington D.C.

Osiński W. 2003, Antropomotoryka. AWF Poznań.

Przetacznik-Gierowska M. 1998, Psychologia wychowawcza. Wydawnictwo Naukowe PWN. Warszawa.

Przewęda R. 1985, Uwarunkowania poziomu sprawności fizycznej polskiej młodzieży szkolnej. Z warsztatów badawczych. AWF Warszawa.

Róg A., Siudzińska S. 2013, Style wychowania stosowane przez rodziców a społeczne funkcjonowanie dziecka, [w:] Rodzicielstwo w kontekście wychowania i edukacji Brągiel J. (red.) Uniwersytet Opolski.

Ryś M. 2004, Systemy rodzinne. Metody badań struktury rodziny, pochodzenia i rodziny własnej. Centrum Medyczne Pomocy Psychologiczno-Pedagogicznej. Warszawa.

Szklarska A. 1998, Społeczne różnice w sprawności fizycznej dzieci i młodzieży w Polsce. Monografie Zakładu Antropologii PAN. Wrocław.

Tabak I. 2013, Struktura i funkcjonowanie rodziny. a aktywność fizyczna młodzieży, [w:] Aktywność fizyczna młodzieży szkolnej w wieku 9-17 lat. Aktualne wyniki. Tendencje ich zmian oraz wybrane zewnętrzne $i$ wewnętrzne uwarunkowania. Raport końcowy. Instytut Matki i Dziecka. Warszawa.

Trempała J. 2011, Psychologia rozwoju człowieka. PWN Warszawa. 